\title{
Approach to management by processes in a sports department of a local government organization
}

\author{
Pedro Alexandre Sobreiro ${ }^{1 *}$, Rita Santos-Rocha², Rui Claudino ${ }^{3}$, António Serôdio- \\ Fernandes 4
}

ARTIGO ORIGINAL | ORIGINALARTICLE

\begin{abstract}
The strategy creates assumptions that should reflect the organization and the surrounding environment. The difficulties in the operationalization of the strategy and the lack of resources for the nonprofit sports organization require effective approaches. This study uses the Business Process Management to support the strategy operationalization using improvement actions according to the existing circumstances of each organization. Based on the action research we analyze the existing situation of nonprofit sports organizations and identify the line of actions to achieve the municipality intended outcomes. The lack of financial resources requires the identification of improvements according to the existing resources. The assessment of the concerns and issues related to stakeholders provides a mechanism to clarify which improvement action should be developed considering the involvement of different board members of the organization. The manager training in nonprofit organizations is an important area to target actions to contribute to the development of the nonprofit organizations, increasing their knowledge. Our findings highlight how the proposed approach can be used in nonprofit sports organization to develop an action plan to engage their business objectives according to its environment.

Keywords: Sports organizations, Strategy Operationalization, Action-research, Business Process Management
\end{abstract}

\section{INTRODUCTION}

The definition of objectives underlies the concept of a Sports Organization, considered by Slack and Parent (2006) goal-oriented, with a structured and delimited activity. The strategy creates a set of ground base axioms to develop the business objectives supported with the necessary means to accomplish it (Chandler, 1962; Das, 1990), reflecting the organizational situation and environment where operate (Thibault, Slack, \& Hinings, 1993). The importance to advance in the strategic planning for the government, public agencies and nonprofit organizations, to fulfill their missions and serve their stakeholders effectively, efficiently and responsibly was reinforced by Bryson (1988). The formulation of the strategy provides clearer objectives, better guidelines for employees, improved organizational performance, and an enhanced ability to anticipate and respond to environmental changes (Das, 1990).

Nevertheless, with the advantages in the strategy formulation, the nonprofit sports organizations have a poor performance in this area, aggravated with the lack of management resources to perform their strategic functions (Ferkins, Shilbury, \& McDonald, 2005). Those difficulties are increased with problems in the areas of volunteers, economy, institutional relations and facilities (Seippel, 2004). Simultaneously, the funding decreasing for the sports sector (Berrett \& Slack, 2001) aggravated this situation, where Portugal with the austerity program imposed by the troika in 2011 (Gorjão, 2012) is not an exception.

\footnotetext{
Manuscript received at January $1^{\text {st }}$ 2018; Accepted at May $14^{\text {th }} 2018$

${ }^{1}$ CIEQV, Sport Sciences School of Rio Maior, ESDRM, IPSANTARÉM, Rio Maior, Portugal

${ }^{2}$ CIPER, Sport Sciences School of Rio Maior, ESDRM, IPSANTARÉM, Rio Maior, Portugal

${ }^{3}$ Faculty of Human Kinetics, University of Lisbon, Lisbon, Portugal

${ }^{4}$ Sports Sciences \& Health Department, University of Trás-os-Montes E Alto Douro, Vila Real, Portugal

* Corresponding author: Escola Superior de Desporto de Rio Maior, ESDRM-IPSANTARÉM, Av. Dr. Mário Soares, 2040-413, Rio Maior, Portugal. E-mail: sobreiro@esdrm.ipsantarem.pt
} 
The environmental changes require organizational adaptability, which according to Miller (1982) is performed slowly. The adaptability responses demand that the organizations act as a processing system to the external environment (Miller \& Friesen, 1983), which is addressed superficially in the sports organizations (Ferkins et al., 2005). However, this problem can be targeted using stakeholders as a source of triggers to process by the organization (Rummler \& Brache, 1995; Sharp, 2009; Coelho, 2010) with an underlying objective (Kaplan \& Norton, 1992) that to be achieved require an improvement action (Harmon, 2007).

The sports organizations are facing new challenges, such as the increasing demands for strategic thinking and action (Shilbury \& Ferkins, 2011), where the strategy is appointed as one of the primary means by which the organizational performance can be improved (Andrews, Boyne, Law, \& Walker, 2009). Despite the importance of the strategy formulation, there is a lack of research on how to implement the strategy (Thibault et al., 1993; Emery, 2010; Slack, 2010).

The nonprofit sports organizations are mainly managed by volunteers (Ferkins et al., 2005), contributing to the process of decision making (Soares, Correia, \& Rosado, 2010) and strategic activities such as vision and mission, and environmental adjustments (Ferkins et al., 2005). The lack of professionals managing the nonprofit sports organizations contributes to the existence of conflicts between paid professionals and volunteers to control the decision making (Hoye, 2004), however, this creates diversity in the human resources that could be beneficial to the decision. According to Ferkins et al. (2005), the board diversity is more suited to the stakeholder's demands and multiple objectives, where the decisions are analyzed and discussed according to the available information and actors interpretation.

Considering the existence of manly volunteers in nonprofit sports organizations, the lack of professionals in the boards, and the inexistence of research in strategy operationalization, it is important to understand how to operationalize the organization strategy according to their business objectives resulting from the environment where operate. The aim of this study is to propose an approach for the nonprofit sports organizations simplify their strategy clarification and operationalization, supported in improvement actions to achieve their business objectives.

\section{THEORETICAL FRAMEWORK}

\section{Why BPM as an approach?}

Business Process Management (BPM) possesses features that could support the strategy operationalization and simplify the clarification of the organizational priorities. BPM supports the business objectives improving the business processes (Aalst, Rosa, \& Santoro, 2016; Jeston, 2018), developing the alignment between the strategy and operations, based in the management of the employees (Harmon, 2010). Møller, Maack, and Tan (2008) considered that BPM has a holistic perspective, using technology to operate and control the entire business through rules that define the business processes.

BPM is also considered a management approach (Jones \& Dixon, 2011; Rosing, Scheel, \& Scheer, 2014; Aalst et al., 2016), holistic (Rosemann \& Brocke, 2010; Jones \& Dixon, 2011; Karagiannis, 2012) to achieve business objectives (Aalst et al., 2016; Jeston, 2018). Rosemann and Brocke (2010) stated that is a management discipline, with a multidisciplinary perspective, integrating the knowledge areas of management, quality control and information technology (Harmon, 2010), also considered a comprehensive system for transforming the operations in the organizations (Hammer, 2010). The benefits from the adoption of BPM results in better performance in the organization, in the dimensions of cost, time, capacity and quality (Hammer, 2010; Rosing et al., 2014). Burlton (2010) suggested methodological support, to align the business strategy, where the processes are a fundamental resource for the strategy (Brenner \& Coners, 2010) that the organization could benefit from its automation (Kirchmer, 2010). Processes are the underlying element to BPM, thus, Weske (2012) defined the process as a collection of related activities that in a specific sequence produces a service or product for a particular customer or customers. 
A business process is a set of steps, projected to produce a product or service (Rosing et al., 2014), generating customer value (Dumas, Rosa, Mendling, \& Reijers, 2013). Kirchmer (2010) also considered, that the value should be generated for the customer, but adds the internal customers. A business process creates value for the customer (Weske, 2012; Dumas et al., 2013), contributing to achieving business objectives (Aalst et al., 2016). The consideration of processes as an element that facilitates the achievement of the business objectives, has led to the emergence of several approaches, intending to develop the alignment between the strategy and processes.

\section{Existing approaches}

The approaches to improve organizations should be developed to maximize their impact in the organizations. There are several approximations developed by practitioners operating in the BPM field that can be considered: Effective Process Framework (Rummler \& Brache, 1995) (Rummler \& Brache, 1995); Office of BPM (Tregear, Alkharashi, Leandro, \& Macieira, 2010); 7FE Project framework (Jeston \& Nelis, 2006); Tools for process improvement (Sharp, 2009); BPM Project Delivery Framework (Miers, 2006); BPTrends (Harmon, 2007) and MLearn (Coelho, 2005b). The existing approaches consider the strategy as a context, framing the processes, which require the development of improvement actions to achieve the business objectives of the nonprofit organization. The development of the improvements should be supported in the clarification of their impact, which requires an evaluation of the business context. An improvement action represents what must be developed in the work performed in the organizations to achieve the strategy (Rummler \& Ramias, 2010; Harmon, 2014). The improvement action should be properly articulated with the organization business strategy.

\section{Proposed approach}

Considering the aforementioned aspects is proposed an approach to support the nonprofit sports clubs based in the articulation of three layers: strategy, operations, and implementation (Figure 1). The strategy is considered a context, using processes to clarify the areas to be targeted, supported in improvement actions (Tregear et al., 2010; Harmon, 2014). To simplify the initial assessment is adopted the concept of business capabilities, allowing to focus in what the organization must do before clarifying how (Sharp, 2011), representing areas giving a competitive advantage to the organization (Prahalad \& Hamel, 1990) and attuned with the concept of the value chain of Porter (1998). The business capability depicts a first hierarchical level of what as to be accomplished by the organization, also representing, what the organization must do to respond to an external stimulus, triggered by their stakeholders.

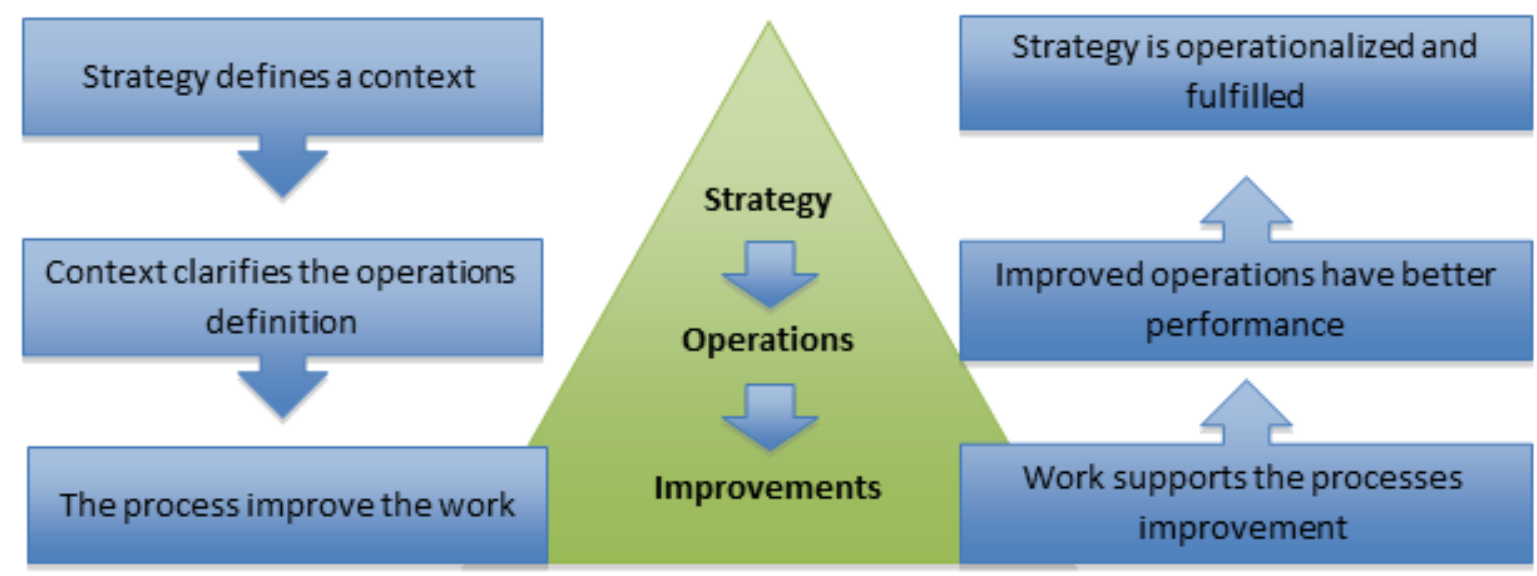

Figure1. Overall approximation to identify the improvement actions in the organization 
For the assessment of the necessary information to develop the meetings with the organization boards, was considered the importance of the existence of several representatives during the meetings, where the diversity is important in the nonprofit sports organizations (Ferkins et al., 2005; Soares et al., 2010). The representatives should be present considering their knowledge and not in functional representation, considered a barrier (Zairi, 1997), which should be removed enabling a better response to a stakeholder (Rummler \& Brache, 1995). According to Ferkins et al. (2005) board diversity is an advantage to deal with several stakeholders.

\section{Approach steps}

The context obtained in the strategy provides the foundations to develop the construction of the alignment and identify the improvement actions. The identified approach steps to develop the alignment were:

1. Mission and Vision: considered the recommendations by the European Foundation for Quality Management (EFQM, 2001), that systematize its definition;

2. Strategic objectives identification: based on the principles presented in the Learn Method (Coelho, 2005a);

3. Stakeholders: based on the identification of a group or individual that can affect or be affected by the fulfillment of the strategic business objectives (Freeman, 1984);

4. Business capabilities: identify skills or abilities that the organization has. It is an abstraction or encapsulation of people, processes and information technologies (Homann, 2006). Describes what the organization has to do, without specifying how, using a black box perspective (Rosen, 2012);

5. Assessment of stakeholders concerns and objectives: detect issues or dissatisfactions in the interaction between stakeholders and the organization, which originates a business objective to correct (Coelho, 2005a);

6. Identification of improvement priorities: based on the identification of the existing resources in the organization to establish the improvement priorities;
7. Definition of an action plan: based on the assessment and analysis developed to create a business context, leads to the identification of improvement projects targeting business capabilities.

The proposed approach step 5 "Assessment of stakeholders concerns and objectives" allows clarifying the relationship between business capabilities, stakeholders, business objectives and improvement actions. The improvement action is executed in a business capability and materialized in a business objective, representing what must be achieved to solve the concern. This approach step provides an interface between the strategy layer and improvements to perform, represented in the operational layer (Figure 1).

\section{METHODS}

This study was methodologically supported in the action-research, since there wasn't an action plan to be developed in the sports clubs to achieve the municipality objectives, which required the active intervention of the researcher. The actionresearch improve knowledge and solves practical problems (Argyris, Putnam, \& Smith, 1985), with a tight coupling of research and action, and the deliberate involvement of the researcher in the changes to the situation being researched (Huxham \& Vangen, 2003). The action-research has the objective to generate organizational change, solve practical problems (Baskerville \& Myers, 2004). According to Lewin (1946), the action-research is research that helps the knowledge generation about the social system targeted and simultaneously develop change.

The theory will be formed from the experience that should be meaningful to others and emerging from the body of theory applied in practice (Eden \& Huxham, 1996), generating a descriptive theory capturing the experienced world using an inductive process (Huxham \& Vangen, 2003).

In our study, the development of the actionresearch was executed for three consecutive months. According to De Vries (2007) the duration of the action-research studies could be between a few months to 10 years. The initial step involved the assessment of the context and 
objectives, followed by the diagnostic, action planning, action taking, and action evaluating (Coghlan \& Brannick, 2005).

This study was developed with a sports department of a municipality (SDM), which agreed to participate in this study and coordinate the involvement of the local nonprofit sports clubs. The study was interventional, based in a process where the researcher and organization members work together. The data was gathered using direct and participative observation during the meetings using interviews. The interview gives the flexibility to select the order, which the various topics are dealt with, using suitable expressions (Corbetta, 2003). Tharenou, Donohue, and Cooper (2007) also stated that their advantage allows discussing scenarios with the interviewer that can be used to identify particular issues. To support the data collection during the interviews was proposed the use of an audio recorder, but the lack of availability by the sport clubs responsible and the advantage to make the participants feel more comfortable relaxed and more willing to voice their opinions (Puhakainen \& Siponen, 2010) led us to the adoption of field notes.

The first steps involved the assessment of the existing situation in the sports department, developing a meeting with the manager of the SDM to confirm the conditions for the execution of the study, the current situation, and the expected outcome. These meetings were followed with interviews with the sports clubs responsible, developing the assessment of the current situation in each sport club, using the proposed approach to identify the improvement actions, followed with the selection of what could be implemented according the resources availability by the responsible of the SDM, which is attuned with the recommendations of Chevalier and Buckles (2013) to prioritize actions according their objectives and restrictions. The last step involved the preparation of the retrieved information to develop a reflection and identify the main conclusions. Next, is described a background, the participants in the study, and how the study was developed.

\section{Background and participants}

According to the SDM, there are 100 sports clubs and associations in the municipality. The regulation of the SDM defines programs and rules underlying the support by the municipality to the cultural, sport and recreational associations with the mission of training, fruition and promoting of the citizens (SDM, 2010). The first meeting with the responsible of the SDM, established the global steps to develop the study (Table 1). The second meeting was developed with the manager of the SDM, sport senior technical and intern, which allowed to the definition of the strategic objectives to achieve:

1. Decentralization of the sports practice, assuring homogeneous participation rates by region;

2. Increase the number of practitioners, assuring greater participation in the different age groups;

3. Identify alternative supports to the sports clubs, minimizing existing difficulties related to the lack of financial autonomy.

These objectives require the clarification of how to engage their operationalization in the sports clubs, based on the identification of improvement actions to contribute to their achievement. The improvement actions in the sports clubs enable the achievement of business objectives, supported on business capabilities.

The participants were selected by the SDM, based on their importance to the region, dimension, board member availability and agreement for conducting the study. The sports clubs were contacted by the SDM to schedule the meetings. The number of selected clubs that agreed to participate in the study were five and was conducted one interview in each club. In figure 3 are represented the developed steps and the number of meetings. The interviews were developed with the meeting participants that were encouraged to participate according to their experience and not in relation to the role performed in the organizations, allowing to contribute freely. All the clubs are managed by volunteers with the following characteristics:

- Sports Club 1 (SC1). Develop its activity in futsal supporting 50 athletes. The elements present were the president, treasurer, secretary and head coach; 
- $\quad$ Sports Club 2 (SC2). The main activity is swimming with 120 athletes and a futsal team with 14 players. The elements present were the president, vice-president and treasurer;

- $\quad$ Sports Club 3. (SC3). Soccer club with 400 athletes in different classes, for men and women. The element present was the president;

- Sports Club 4. (SC4). Develop various sporting activities namely: karate; swimming; amateur football teams; professional football team; veteran football team; mountain biking and duathlon, with 255 athletes. The element present was the president;

- Sports Club 5. (SC5). The main activity is athletics with 150 practitioners, from which 107 are federated athletes. The element present was the technical director on behalf of the president.

To maintain their anonymity was used an identification tag suffixed with a sequential number representing each sports club evaluated. The development of the data collection was based on the analysis of statutes, internal regulation and interviews (individual and group).

\section{Study development}

The first contact with the sports clubs, allowed to develop the assessment of the "Mission and Vision" which was supported in the regulation of the SDM (SDM, 2010). The strategic objectives were also identified in the first contact. The following steps were developed based in the interviews with the sports clubs.

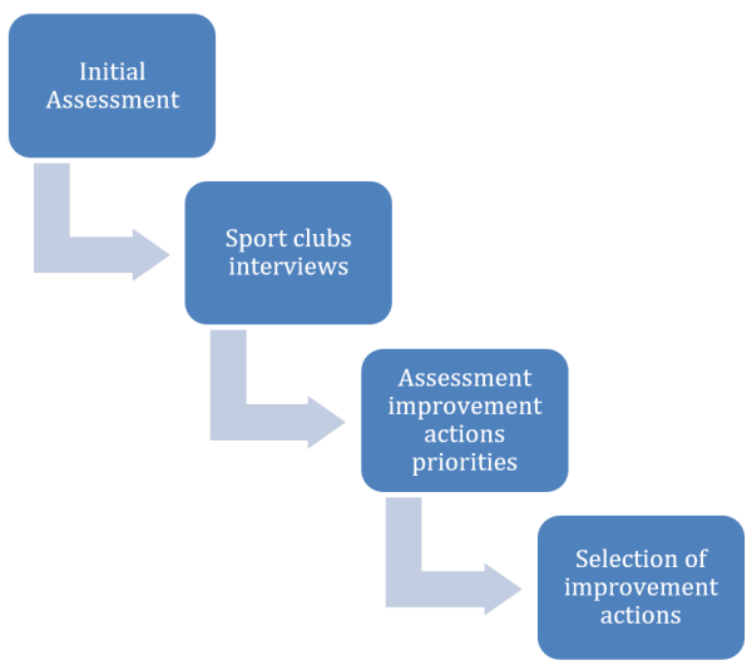

Figure 2. Two meetings were developed in the Initial Assessment, followed with five meetings in the sports clubs. The final step involved the assessment of improvement actions priorities and the selection of improvement actions required.

Table1

Global steps developed during the context clarification with the responsible

\begin{tabular}{|c|c|c|c|}
\hline Steps & Overview & Results & Participants \\
\hline Awareness & $\begin{array}{l}\text { Understanding of the current } \\
\text { situation; Identification of the study } \\
\text { assumptions; Articulation of the } \\
\text { approach to develop, with the } \\
\text { involvement of the sport science } \\
\text { school as project partner, and the } \\
\text { municipality as an enabler and } \\
\text { interested partner in the promotion } \\
\text { of the region using sport clubs. }\end{array}$ & $\begin{array}{l}\text { Articulation of the following } \\
\text { sessions. Presentation of the work } \\
\text { to develop involving the project } \\
\text { participants: Municipality; Sports } \\
\text { Sciences School and research team. } \\
\text { Identification of the Sports Clubs } \\
\text { for the development of the work in } \\
\text { the Municipality. }\end{array}$ & $\begin{array}{l}\text { (1) Responsible for } \\
\text { the sports sector in } \\
\text { the municipality (2) } \\
\text { Sports Senior } \\
\text { Official (3) Sports } \\
\text { Management Intern }\end{array}$ \\
\hline $\begin{array}{l}\text { Presentation of the } \\
\text { conclusions of the } \\
\text { information retrieved } \\
\text { in the sport clubs }\end{array}$ & $\begin{array}{l}\text { Presentation of the work developed } \\
\text { to obtain an action plan according to } \\
\text { the real needs of the municipality in } \\
\text { a global context to improve the } \\
\text { sports practice. }\end{array}$ & $\begin{array}{l}\text { Conclusions of the study and } \\
\text { development of a work session to } \\
\text { clarify the areas where is possible } \\
\text { to develop an intervention in the } \\
\text { actual context. }\end{array}$ & $\begin{array}{l}\text { (1) Responsible by } \\
\text { the sports } \\
\text { department in the } \\
\text { municipality (2) } \\
\text { Sports Senior } \\
\text { Official (3) Sports } \\
\text { Management Intern }\end{array}$ \\
\hline $\begin{array}{l}\text { Identification of the } \\
\text { improvement actions } \\
\text { to develop }\end{array}$ & $\begin{array}{l}\text { Analysis of the issues identified and } \\
\text { the respective improvement actions. } \\
\text { Identification of the target areas in a } \\
\text { context of the existing capabilities in } \\
\text { the municipality. }\end{array}$ & $\begin{array}{l}\text { Potential improvement actions to } \\
\text { develop in the current context }\end{array}$ & $\begin{array}{l}\text { Responsible by the } \\
\text { sports department } \\
\text { in the municipality }\end{array}$ \\
\hline
\end{tabular}
the municipality.

Note: The developed steps, results and participants, to identify a necessary context for the development of an action plan according to the requirements identified by the municipality.

After the initial assessment with the sports department, the interviews were developed with the nonprofit sports clubs, considering the several perspectives already presents in the approach steps, which we generally describe (Table 2). The assessment of the Mission and 
Vision is based on the topic " 1 . What does your sports club?" to identify the mission, the topics "2. What your sports club intended to be?" and "3. What is the sports club ambition?" helps the clarification of the organization vision. The topics "4. What are the necessary supports to increase the number of practitioners?", " 5 . What is the necessary support to increase the number of classes?" and "6. What is necessary to do to increase the revenues?" allow the identification of the strategic objectives. The identification of the stakeholders was based in "7. Who contributes to or causes difficulties to achieve the sport club objectives?"

The assessment of the business capability considered that represents " 8 . What the sports club should do?", which gives a competitive advantage to the organization (Prahalad \& Hamel, 1990) and allow to reflect on the root issues (Rosen, 2012), generating value to the organization (Porter, 1985) "9. What does the sports club know to do?". To clarify the identified business capability was also described its meaning, to simplify the comprehension of what represents in the context of the work being developed, and how should be interpreted. The issues and concerns were based on the topic " 10 . What are the main issues or concerns related to a stakeholder?", "11. How to solve an issue or concern related to a stakeholder?" and " 12 . What is the objective that has to be achieved to remove an issue or concern?".

These assumptions were used for the development of the interview and allowed the gathering of the necessary information. After the development of the interviews the retrieved information was inserted in a spreadsheet representing the concerns (Figure 3) and integrated into each step of the proposed approach.

Table 2

Interview topics

\begin{tabular}{|c|c|c|}
\hline Step & Approach element & Topic to be addressed \\
\hline 1. Mission and Vision & Mission & $\begin{array}{l}\text { (1) What does your sports club? } \\
\text { (2) What sports club intend to be? } \\
\text { (3) What is the sports club ambition? }\end{array}$ \\
\hline 2. Strategic objectives & $\begin{array}{l}\text { Increase the number of } \\
\text { practitioners } \\
\text { Increase the number of } \\
\text { existing levels } \\
\text { Increase revenues }\end{array}$ & $\begin{array}{l}\text { (4) What are the necessary supports to increase the } \\
\text { number of practitioners? } \\
\text { (5) What is the necessary support to increase the } \\
\text { number of levels? } \\
\text { (6) What is necessary to increase revenues? }\end{array}$ \\
\hline $\begin{array}{l}\text { 3. Stakeholder } \\
\text { assessment }\end{array}$ & Stakeholders & $\begin{array}{l}\text { (7) Who contributes to or causes difficulties to achieve } \\
\text { the sport club objectives? }\end{array}$ \\
\hline $\begin{array}{l}\text { 4. Assessment of } \\
\text { Business capabilities }\end{array}$ & Business Capability & $\begin{array}{l}\text { (8) What the sports club should do? } \\
\text { (9) What does the sports club know to do? }\end{array}$ \\
\hline \multirow[t]{2}{*}{$\begin{array}{l}\text { 5. Issue assessment } \\
\text { related to } \\
\text { stakeholders }\end{array}$} & $\begin{array}{l}\text { Issues that concern us } \\
\text { related to a stakeholder }\end{array}$ & $\begin{array}{l}\text { (10) What are the main issues or concerns related to a } \\
\text { stakeholder (identified in the previous step)? } \\
\text { (11) How to solve an issue or concern related to a } \\
\text { stakeholder? } \\
\text { (12) What is the objective that has to be fulfilled to } \\
\text { remove the issue? }\end{array}$ \\
\hline & $\begin{array}{l}\text { What is the necessary } \\
\text { business capability to } \\
\text { solve the issue }\end{array}$ & $\begin{array}{l}\text { (13) What objective as to be achieved to remove an issue } \\
\text { or concern? }\end{array}$ \\
\hline
\end{tabular}

Note: This interview supports the information retrieving, based on the proposed approach. 


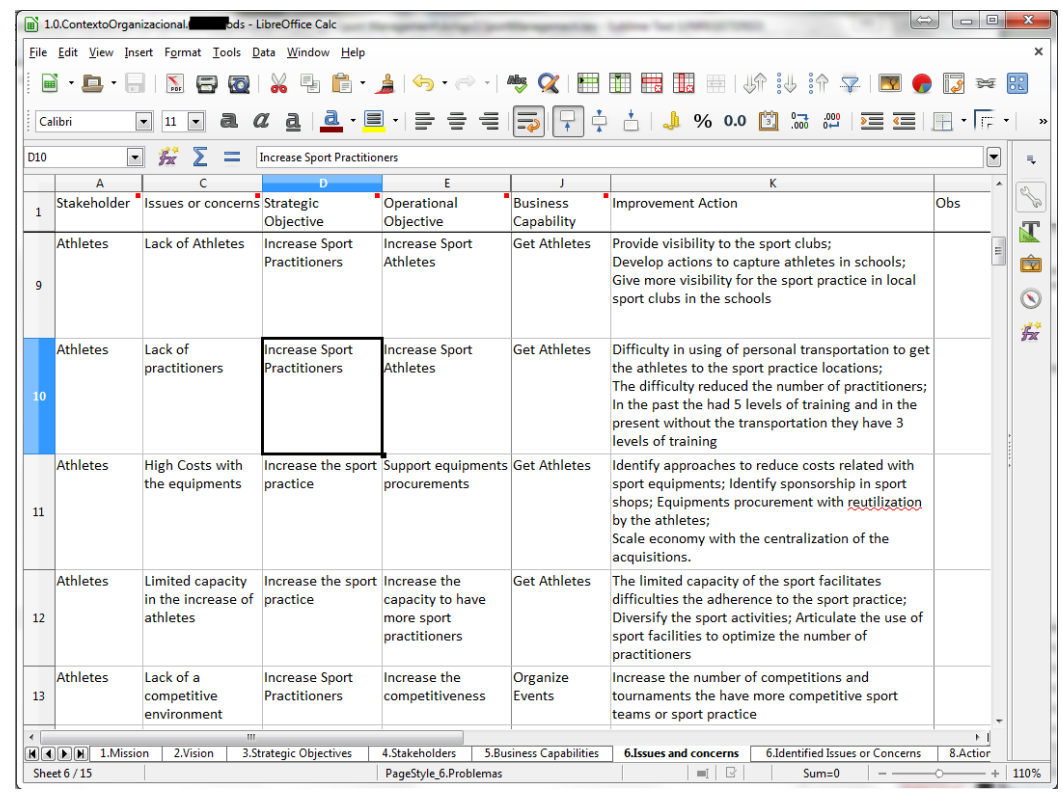

Figure 3. Spreadsheet used to store the information retrieved in the developed meetings

\section{RESULTS}

The results are presented according to the research objectives. First are identified the initial assessment required for the definition of the business objectives, finally are presented the improvement actions.

\section{Initial Assessment}

Figure 4 shows the stakeholders identified by the participants in the interviewed sports clubs. Some stakeholders were identified considering their importance for the development of sports events, such as "Scouts" and "Church members", namely for their support and promotion respectively.

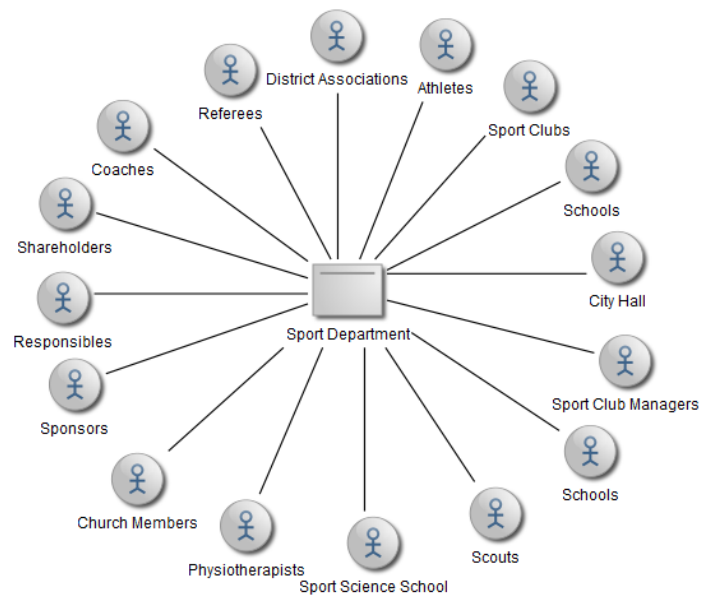

Figure 4. Identified stakeholders

After the identification of the stakeholders, the conditions for the assessment of the business capabilities were fulfilled, reflecting import skills or abilities that the sports organization should have. The study participants in the sports clubs 1 , 3 , and 5 considered fundamental to ensure the sports club survival, the capability to increase new members, athletes or other members.
"We need to increase the visibility of the clubs and develop actions to attract athletes" (Sports manager of the sports club SC1)

"The cost with the equipment's should be reduced and promoted their reuse to reduce

costs for athletes starting to play soccer" (Sports manager of the sports club SC3)

"To attract members we have to develop partnerships with schools and sport events to identify new talents" (Sports manager of the sports club SC5) 
This leads to an identified business capability "Get Members", which was split in "Get Athletes" and "Get Sports Members". This division reflects the differences in what the organization must do to increase or renew the athletes and increase or retain the sport club members. This assumption was adopted in the assessment of all the business capabilities, reflecting what the organization must do to in reaction to a stimulus triggered by a stakeholder. To retain athletes and sports members were also considered important the "Satisfaction Assessment" and "Retain Athletes". The importance of the training or formation of the athletes and practitioners is represented in "Develop Training".

The concern for the sports clubs increases profits is represented in the business capabilities to "Get Sponsorship" and "Organize Events". The organization and management of the sports club were also considered a fundamental ability for the Sports Club, which is identified in "Manage Sports Club". This capability was considered to have a crucial role to articulate the several areas of the organization, or the identified business capabilities. The participants also considered the business capability "Communicate and Disseminate" important for the promotion of the club activities, events or results. In Table 3 are represented the identified business capabilities and their description.

\section{Identification of the business objectives}

After the retrieved information it is possible to integrate the identified constructs based on the assessment of the issues and concerns related to the stakeholders. The resolution of an issue and a concern is accomplished using an objective, which if it is fulfilled the issue is solved. The objective fulfillment is supported by a business capability that must be improved to correct the gap between the current state and a desired one. Simultaneously, the operational objective is associated with a strategic objective, to support the alignment of the lower level objectives with the upper level. These assumptions were used to frame the issues or concerns identified by the sports clubs.
"Our concern in relation to the schools is the lack of partnerships to attract athletes. Our objective is to increase the number partnership and recruited athletes. To achieve this objective, we have to develop partnerships with schools and the teachers of physical activity to develop athletes tracking."

(Sports manager of the sports club SC4)

Table 3

Sports clubs identified business capabilities

\begin{tabular}{|c|c|}
\hline $\begin{array}{l}\text { Business } \\
\text { Capability }\end{array}$ & Description \\
\hline Get Athletes & $\begin{array}{l}\text { Get athletes and practitioners which } \\
\text { is fundamental for the existence of } \\
\text { the sports club and renewal of their } \\
\text { practitioners }\end{array}$ \\
\hline $\begin{array}{l}\text { Get Sports Club } \\
\text { Members }\end{array}$ & $\begin{array}{l}\text { Get sport club members contributing } \\
\text { with financial and non-financial } \\
\text { supports }\end{array}$ \\
\hline $\begin{array}{l}\text { Satisfaction } \\
\text { Assessment }\end{array}$ & $\begin{array}{l}\text { Understand the satisfaction with the } \\
\text { sports clubs and what athletes, } \\
\text { practitioners, members and sponsors } \\
\text { intend }\end{array}$ \\
\hline $\begin{array}{l}\text { Communicate } \\
\text { and Disseminate }\end{array}$ & $\begin{array}{l}\text { Communicate and inform what is } \\
\text { performed and what is intended to } \\
\text { carry }\end{array}$ \\
\hline $\begin{array}{l}\text { Develop } \\
\text { Training }\end{array}$ & $\begin{array}{l}\text { Train athletes for the sports activity } \\
\text { including social and ethical values }\end{array}$ \\
\hline $\begin{array}{l}\text { Manage Sport } \\
\text { Club }\end{array}$ & $\begin{array}{l}\text { Manage the sports club to develop its } \\
\text { business capabilities optimally. } \\
\text { Includes legal and social } \\
\text { responsibilities. }\end{array}$ \\
\hline $\begin{array}{l}\text { Manage Human } \\
\text { Resources }\end{array}$ & $\begin{array}{l}\text { Manage volunteers, board members, } \\
\text { coaches, parents and other members } \\
\text { related to the sport club }\end{array}$ \\
\hline Get Sponsorship & $\begin{array}{l}\text { Develop new approaches to get } \\
\text { sponsors, fundraising, or other } \\
\text { resources that the sports club needs } \\
\text { to develop its activity }\end{array}$ \\
\hline Organize Events & $\begin{array}{l}\text { Plan, organize and execute sports } \\
\text { events fundamental to disclose the } \\
\text { club and increase revenues }\end{array}$ \\
\hline Retain Athletes & $\begin{array}{l}\text { Develop and execute approaches to } \\
\text { retain the athletes in the sports club. }\end{array}$ \\
\hline
\end{tabular}

The concern identified by the sports manager in the sports club SC4 was framed in strategic objective increase the number of practitioners and supported in the business capability "Get Athletes". Each issue or concern related to a stakeholder originates an objective. Each objective stipulates the necessary conditions to support the achievement of the strategic objectives and simultaneously the resolution of the issue or concern. This approach was developed to each stakeholder. 
"The monthly payment as to have lower values in the first year of sport practice facilitating the attraction of new athletes."

"We have to increase sponsorship to support the reduction of the first year monthly payment or reduce the tuition fees globally."

"The bar revenues are not possible because the bars are installed away from the practice and competition sites."

(Sports manager of the sports club SP2)

The identification of the concerns and issues support the definition of the objectives. In table 4, we have an assessment of the issues or concerns related to athletes' stakeholders. The business capability related to the issue or concern supports the improvement to achieve the gap correction associated with a business objective. The evolution related to the improvement in the business capability is monitored using a business indicator to evaluate its progression to accomplish the business objective. Figure 3 presents the integration of stakeholders, concerns, business objectives, capabilities and improvement actions, linked to a strategic objective.

Table 4

Issues and concerns related to athletes

\begin{tabular}{|c|c|c|c|c|}
\hline $\begin{array}{l}\text { Issues or } \\
\text { concerns }\end{array}$ & $\begin{array}{l}\text { Strategic } \\
\text { objective }\end{array}$ & $\begin{array}{l}\text { Business } \\
\text { Objective }\end{array}$ & $\begin{array}{l}\text { Business } \\
\text { Capability }\end{array}$ & Improvement Action \\
\hline Low revenues & $\begin{array}{l}\text { Sports Club } \\
\text { Revenues }\end{array}$ & $\begin{array}{l}\text { Increase the } \\
\text { revenues } \\
\text { obtained in } \\
\text { tuition fees }\end{array}$ & $\begin{array}{l}\text { Get Sports } \\
\text { Club Members }\end{array}$ & $\begin{array}{l}\text { Increase the number of athletes to increase the } \\
\text { tuition fees related to the practice. Develop } \\
\text { strategies to increase the athletes paying to } \\
\text { support the sports practice. }\end{array}$ \\
\hline $\begin{array}{l}\text { High costs with } \\
\text { equipment }\end{array}$ & $\begin{array}{l}\text { Increase the } \\
\text { sport practice }\end{array}$ & $\begin{array}{l}\text { Support } \\
\text { equipment } \\
\text { procurement }\end{array}$ & Get Athletes & $\begin{array}{l}\text { Identify approaches to reduce costs related to } \\
\text { sports equipment; Identify sponsors in sports } \\
\text { shops; Equipment procurement with } \\
\text { utilization by the athletes; Achieve economy of } \\
\text { scale economy with the centralization of the } \\
\text { acquisitions. }\end{array}$ \\
\hline $\begin{array}{l}\text { Reduced ability } \\
\text { to "get } \\
\text { athletes" }\end{array}$ & $\begin{array}{l}\text { Increase the } \\
\text { sport practice }\end{array}$ & $\begin{array}{l}\text { Increase the } \\
\text { capability to } \\
\text { have more } \\
\text { athletes }\end{array}$ & Get Athletes & $\begin{array}{l}\text { The sports facilities have limited capacity to } \\
\text { simultaneously practitioners. Develop } \\
\text { strategies to articulate practitioners } \\
\text { simultaneously. }\end{array}$ \\
\hline
\end{tabular}

Note: This table represents a part o the issues and concerns related to the stakeholder athletes, after the development of the interview.

\section{Improvement actions}

The information retrieved allows us to have an overall perspective and to develop an assessment of the improvement actions that can be engaged to support the achievement of the strategic objectives. The improvement actions contribute to the achievement of a business objective, which supports the strategic objective. This relationship allows the integration of top-level strategic objectives with business objectives supported in lower level improvement actions targeting business capabilities.

The improvement actions were analyzed according to the availability of the SDM to support the improvement actions (Table 5). The responsible by the SDM identified the improvement actions, which are options to develop its operationalization by the municipality. This allowed establishing the identification of improvement priorities.

"In this context we cannot support financially, but we can use available resources to develop initiatives." (Responsible for the SDM)

The assessment of what can be supported, restricted the business capabilities to "Manage Sports Club", despite being also identified "Manage human resources" or "Develop Training", which the interviewed sports managers considered relevant for the organization. The evaluation of the improvement actions allowed also the identification the business capabilities more relevant, clarifying the priority areas to target enhancements.

"The identified business capabilities provide us areas to make a proposal for training." (Responsible for the SDM) 
Table 5

Evaluation of the improvement actions by the SDM

\begin{tabular}{llllll}
\hline Stakeholder & $\begin{array}{l}\text { Issues or } \\
\text { concerns }\end{array}$ & $\begin{array}{l}\text { Strategic } \\
\text { objective }\end{array}$ & $\begin{array}{l}\text { Operational } \\
\text { Objective }\end{array}$ & $\begin{array}{l}\text { Business } \\
\text { Capability }\end{array}$ & Improvement Action \\
asstrict & $\begin{array}{l}\text { Athletes } \\
\text { registration } \\
\text { costs }\end{array}$ & $\begin{array}{l}\text { Sports Club } \\
\text { Revenue }\end{array}$ & $\begin{array}{l}\text { Reduce } \\
\text { registration } \\
\text { costs }\end{array}$ & $\begin{array}{l}\text { Manage } \\
\text { Sport Club }\end{array}$ & $\begin{array}{l}\text { Assess the extent of costs associated with } \\
\text { the registration of athletes by the sports } \\
\text { clubs of the region. Support the } \\
\text { inscription of federated athletes. }\end{array}$ \\
\hline $\begin{array}{l}\text { District } \\
\text { associations }\end{array}$ & $\begin{array}{l}\text { Costs to train } \\
\text { sport coaches }\end{array}$ & $\begin{array}{l}\text { Increase the } \\
\text { sport practice }\end{array}$ & $\begin{array}{l}\text { Support the } \\
\text { training of sport } \\
\text { coaches }\end{array}$ & $\begin{array}{l}\text { Manage } \\
\text { Human } \\
\text { Resources }\end{array}$ & $\begin{array}{l}\text { Increase resources for to the coach } \\
\text { certification. Negotiate with district } \\
\text { associations the development of an } \\
\text { integrated action. Support fundraising. } \\
\text { Develop an articulated train action after } \\
\text { an initial assessment, considering the }\end{array}$
\end{tabular}
needs of all sports clubs.

\begin{tabular}{|c|c|c|c|c|c|}
\hline $\begin{array}{l}\text { District } \\
\text { associations }\end{array}$ & $\begin{array}{l}\text { Low visibility of } \\
\text { women's } \\
\text { football }\end{array}$ & $\begin{array}{l}\text { Decentralizatio } \\
\mathrm{n} \text { of the sport } \\
\text { activity }\end{array}$ & $\begin{array}{l}\text { Be a reference in } \\
\text { the women's } \\
\text { football }\end{array}$ & $\begin{array}{l}\text { Manage } \\
\text { Sports Club }\end{array}$ & $\begin{array}{l}\text { Transform the district to a reference in } \\
\text { the women's football, increasing } \\
\text { competitiveness, reduce the registrations } \\
\text { costs and match fee to half. }\end{array}$ \\
\hline Athletes & $\begin{array}{l}\text { Children } \\
\text { transport laws } \\
\text { and lack of } \\
\text { resources to } \\
\text { acquire } \\
\text { transportation }\end{array}$ & $\begin{array}{l}\text { Sports Clubs } \\
\text { Revenues }\end{array}$ & $\begin{array}{l}\text { Report the } \\
\text { situation to the } \\
\text { authorities. } \\
\text { Facilitate the } \\
\text { generation of } \\
\text { revenues. }\end{array}$ & $\begin{array}{l}\text { Manage } \\
\text { Sports Club }\end{array}$ & $\begin{array}{l}\text { Increase the availability in the } \\
\text { transportation of the athletes and } \\
\text { simultaneously solve the issue related } \\
\text { with the age of the transport van. Vans } \\
\text { older than sixteen years cannot transport } \\
\text { children with less than sixteen years, } \\
\text { even with inspection done. Legislation } \\
13 / 2006 \text { of } 17 \text { April, covering the public } \\
\text { transportation of children, under the } \\
\text { context of the legislation for scholar } \\
\text { transportation. }\end{array}$ \\
\hline Athletes & $\begin{array}{l}\text { High costs with } \\
\text { sport equipment }\end{array}$ & $\begin{array}{l}\text { Increase the } \\
\text { sport practice }\end{array}$ & $\begin{array}{l}\text { Support for } \\
\text { equipment } \\
\text { acquisition }\end{array}$ & $\begin{array}{l}\text { Develop } \\
\text { training }\end{array}$ & $\begin{array}{l}\text { Identify approximations to reduce costs } \\
\text { related to the sports equipment; } \\
\text { Sponsorship by stores of sports } \\
\text { equipment; Development of } \\
\text { procurement approaches and } \\
\text { centralization of acquisitions; } \\
\text { Acquisition of equipment for the } \\
\text { utilization by the athletes, considering its } \\
\text { reutilization in the future. }\end{array}$ \\
\hline
\end{tabular}

Note: Information retrieved during the development of the approach steps. The improvement actions were evaluated according to the existing resources of the SDM.

After the identification of the priorities, were defined projects sheets to clarify improvement actions. The projects were identified according to the existing abilities in the municipality, and represent what is necessary to accomplish, to correct existing gaps against to what is expected to fulfill, according to the identified objectives. To reduce the number of projects, was realized the integration of similar improvement actions, the definition of the project sheets was simplified based in a template (Table 6), using project definitions guidelines (EFQM, 2001; Tague, 2005; Coelho, 2013) and using the information resulting from the development of the approach steps (Figure 5).

The assessment by the SDM led to the proposal of a training program, to be developed by the municipality, oriented to the improvement of the skills and competencies of the people related to the sports club, in areas important for the organization. To improve the knowledge of the sport club managers, allowing increasing their performance in strategic thinking and action. This identifies an area where should be important to adopt a policy targeting the improvement of the sports managers knowledge. 
Table 6

Project sheet model

\begin{tabular}{ll}
\hline \multicolumn{1}{c}{ Project field } & Field description \\
\hline Project: & Project identification \\
\hline Project description: & Business capability targeted to develop an improvement action \\
\hline Business Capability: & Responsible for implementing the project \\
\hline Responsible: & $\begin{array}{l}\text { Long description of the project, includes the value to determinate the project } \\
\text { ranking; project description and what is its source, i.e. operational objective } \\
\text { and business capability. }\end{array}$ \\
\hline Project Description: & Describes what is intended to accomplish with the project \\
\hline Project objectives: & Expected results by the project development \\
\hline Project results: & The operational objective that is related to the project \\
\hline Business Objectives: & $\begin{array}{l}\text { Identification of the strategic objectives associated with the project, } \\
\text { allowing defining the impact of the project in the strategic objectives. }\end{array}$ \\
\hline Strategic Objectives: & Considering its importance to the organization to implement the project \\
\hline Priority: & When is expected the project to start \\
\hline Scheduled beginning date: & Project implementation and execution length \\
\hline Project length: & The estimated cost for project execution \\
\hline Cost: & $\begin{array}{l}\text { Detailed information related to the project operationalization or additional } \\
\text { information considered relevant. }\end{array}$ \\
\hline Obs: & Actions to develop to accomplish the project objectives \\
\hline Actions: &
\end{tabular}

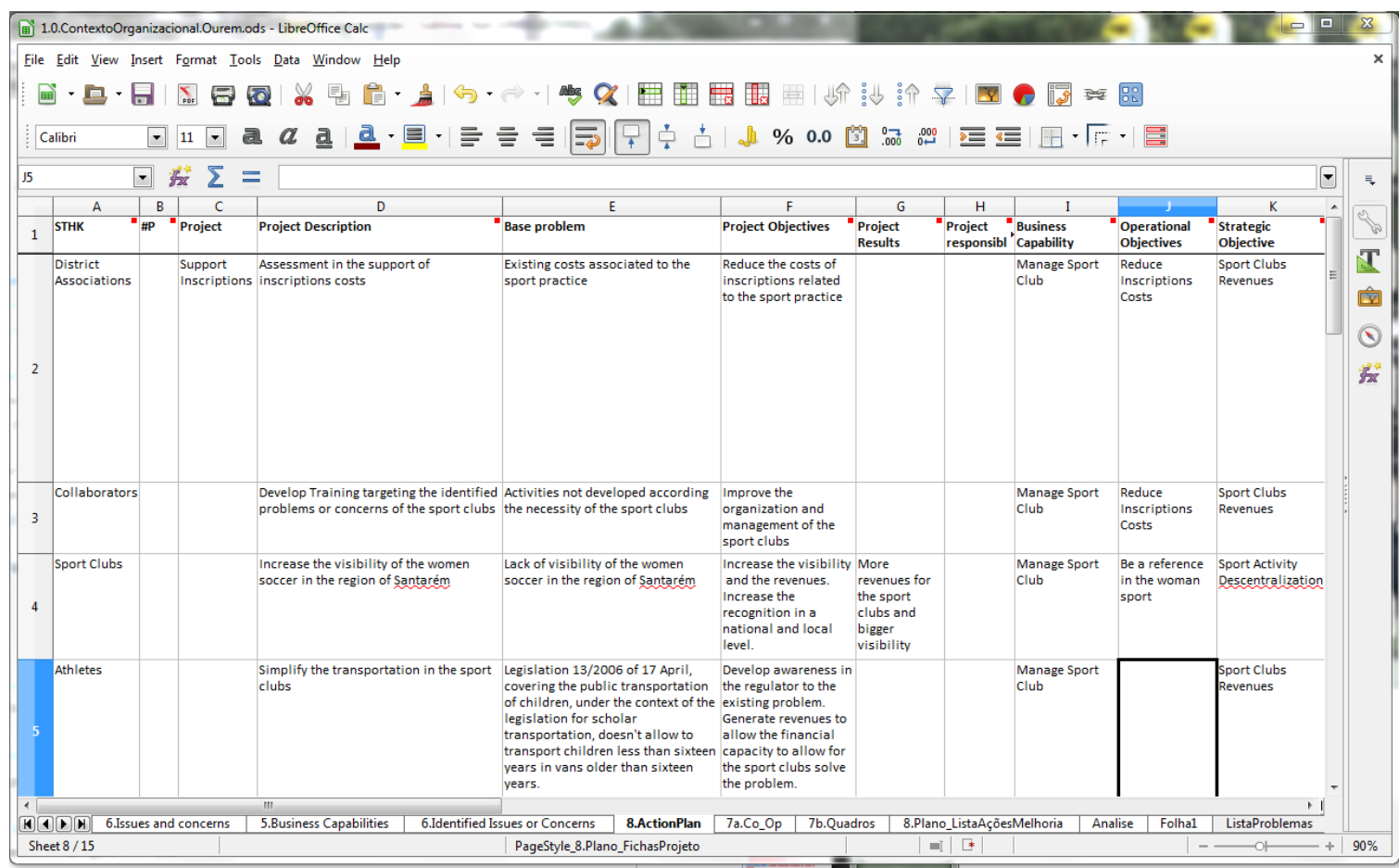

Figure 5. Project sheets definition

\section{DISCUSSION}

The aim of this study is to propose an approach for the nonprofit sports organizations simplify their strategy clarification and its operationalization, supported in improvement actions to achieve business objectives. However, according to Stacey (2011) the strategy clarification should not be developed as a prescription and should be a reflection about the strategy itself and the board members perspective, which as impact on the strategy itself. This perspective implies a less prescriptive approach in the early stages of the proposed approach and more reflective in the strategy 
formulation, allowing the development in the subsequent steps as proposed.

The strategy operationalization should be developed with the involvement of different board members, which is more suited for stakeholders demands and multiple objectives (Ferkins et al., 2005), where could be also involved other stakeholders identified, without being limited only to the board members. Considering other stakeholders, such as schools or athletes, supporting a better reflection of the strategy and the identification of improvement actions.

The study revealed in early stages, the lack of financial resources, which required the definition of business objectives to identify alternative supports for the sports clubs, minimizing the difficulties related to the lack of financial resources. The lack of funding in the sports organizations had already been described in other investigations (Berrett \& Slack, 2001), which has been aggravated in the Portuguese context (Gorjão, 2012). The initial contacts revealed a barrier to developing the study, the lack of availability to use an audio recorder during the meetings, which is recommended (e.g. Ferkins et al., (2005)). This difficulty was addressed also by Rapoport (1970).

During the development of the study, the assessment of the stakeholder concerns allowed the identification of business objectives, which to be achieved requires the development of improvements in the sports club to solve the concern. This allows the clarification of the response that the organization needs to perform to the external environment, triggered by the stakeholder. According to Ferkins et al. (2005) the response to the external environment is a topic superficially explored by sport managers scholars, that could benefit from the board diversity to identify different perspectives. The identified improvement actions based on the stakeholders, support the decision to establish strategic priorities, contributing to solving an existing difficulty already described in the literature (Shilbury \& Ferkins, 2011).

The lack of knowledge in areas such as "Manage Sports Club" was a requirement often referred. The sports club board members need specific training. This seems attuned with the research findings of Thiel and Mayer (2009) stating that sports club managers seem unable to work efficiently without special knowledge about how voluntary sports organizations execute their activity. The idea expressed by Seippel (2004) discussing the major obstacles such as the economy, volunteers, leaders, trainers and recruiting, was also found in the identified business capabilities, considered important by the sports club boards.

Education and training are mechanisms to increase the knowledge of sports club managers, which could be supported with the development of a policy targeting the knowledge of the sports club managers in fundamental areas for sports club survival. This could sustain the improvement of the performance of the sports clubs using its business capabilities. The proposal for a training cycle for the sports managers highlights the demand for knowledge to increase their strategic thinking and action, perspective already identified by Shilbury and Ferkins (2011).

The hinders of this study are related to the implementations of the improvement actions, although being identified, its implementation is fundamental to assess the success of the adopted approach. The achievement of business objectives using the solutions articulated is a confirmation that needs to be developed, allowing the assessment of the effectiveness of the proposed approach, and successfully relate the business objectives to its operationalization.

This study allowed to create a solution where there wasn't one available, using the adoption of action-research to enable the researcher applying prescriptions, which is also suggested by Ferkins et al. (2005). This supports the alignment of the strategic objectives and the improvement actions according to the organizational context. The development of this alignment is a hiatus in the research (Thibault et al., 1993; Emery, 2010; Slack, 2010) that this study exemplifies how can be addressed.

The identified improvement actions based on the assessment of the concerns (Table 4) are attuned with the main obstacles for the sports clubs. This was already described by Seippel (2004) with the identification of elements such as 
economy, institutional relations and facilities. The economic obstacle underlies the development of this study allowing the identification of improvement actions.

\section{CONCLUSIONS}

This study evaluates the adoption of an approach for the non-profit sports organizations simplify their strategy clarification and operationalization. Through action-research, we identified actions to develop considering existing resources in the organization materialized in an action plan, using Business Process Management as an underlying assumption. The work developed will be useful for similar organizations and similar studies.

The lack of resources in the sports clubs is a problem, where the adopted approach could help the development of the strategy operationalization systematically, solving a research gap in sports management simultaneously. The assessment of the concerns and issues related to each stakeholder simplifies the identification of the business objectives, to be achieved using improvement actions.

The board diversity provides wider perspectives and a richer assessment, identifying what should be developed in the organization. What the organization must achieve streamlines what should be developed according to existing organizational resources.

The developed research enhances the importance to improve sports managers knowledge in the areas related to management of the nonprofit sports club, providing an approach to increase their strategic thinking and action, and organizational efficiency. This requires the need to adopt a policy to improve the skills of the managers according to business objectives.

The clarification of what the nonprofit sports organization must fulfill simplifies the prioritization of what must be developed according to existing organizational resources. The lack of professionals in nonprofit sports organizations highlights the importance to continue developing this initiative.

This study tried to develop systematically the identification of operational solutions targeting a strategic context, using a set of steps based on the proposed approach, which simplifies the strategy clarification for nonprofessional sports managers.

Acknowledgments:

Nothing to declare

Conflict of Interest:

Nothing to declare

Funding:

Nothing to declare

\section{REFERENCES}

Aalst, W. M. P. van der, Rosa, M. L., \& Santoro, F. M. (2016). Business Process Management. Business $\mathcal{E}$ Information Systems Engineering, 58(1), 1-6. doi:10.1007/s12599-015-0409-x

Andrews, R., Boyne, G. A., Law, J., \& Walker, R. M. (2009). Strategy Formulation, Strategy Content and Performance. Public Management Review, 11 (1), 1-22. doi:10.1080/14719030802489989

Argyris, C., Putnam, R., \& Smith, D. M. (1985). Action science. San Francisco: Jossey-Bass.

Baskerville, R., \& Myers, M. D. (2004). Special Issue on Action Research In Information Systems: Making IS Research relevant to practice foreword. Management Information Systems Quarterly, 28(3), 2.

Berrett, T., \& Slack, T. (2001). A Framework for the Analysis of Strategic Approaches Employed by Non-profit Sport Organisations in Seeking Corporate Sponsorship. Sport Management Review, 4(1), 21-45. doi:10.1016/S1441-3523(01)70068$\mathrm{X}$

Brenner, M., \& Coners, A. (2010). Process Capital as Strategic Success Factor: The Lufthansa Example. Handbook on Business Process Management 2, 57-72. doi:10.1007/978-3-642-01982-1 3

Bryson, J. M. (1988). A strategic planning process for public and non-profit organizations. Long Range Planning, 21(1), 73-81. doi:10.1016/00246301(88)90061-1

Burlton, R. (2010). Delivering Business Strategy Through Process Management. Handbook on Business Process Management 2, 5-37.

Chandler, A. D. (1962). Strategy and structure: Chapters in the history of the american enterprise. Massachusetts Institute of Technology Cambridge.

Chevalier, J. M., \& Buckles, D. (2013). Participatory action research: theory and methods for engaged inquiry. Abingdon, Oxon; New York, NY: Routledge.

Coelho, J. (2005a). Arquitectura da empresa centrada nos processos: o factor determinante para o alinhamento estratégico dos SI. In L. Amaral, R. Magalhães, C. Morais, A. Serrano, \& C. Zorrinho 
(Eds.), Sistemas de Informação Organizacionais (pp. 141-197). Lisboa: Edições Sílabo.

Coelho, J. (2005b). BPM and Continuous Improvement. In Search of BPM Excellence: Straight from the Thought Leaders, 119-130.

Coelho, J. (2010). How to align information systems requirements? - Mlearn approach. In Industrial Track, conference proceedings. Porto. Retrieved from http://repositorium.sdum.uminho.pt/bitstream/ 1822/21556/1/Dialogical\%20Action\%20Researc h\%20for\%20Better\%20Enterprise\%20Architectu re\%20Implementation.pdf

Coelho, J. (2013, April). Alignamento estratégico dos SI/TIC: Metodologia MLearn. Presented at the Formação BPM - Arquitetura de Processos, AIP Lisboa.

Coghlan, D., \& Brannick, T. (2005). Doing action research in your own organization (2nd ed). London: Sage Publications.

Corbetta, P. (2003). Social Research: Theory, Methods and Techniques. London; Thousand Oaks, Calif: SAGE Publications Ltd.

Das, H. (1990). Organization theory with Canadian applications. Toronto: Gage Educational Pub. Co.

De Vries, E. J. (2007). Rigorously Relevant Action Research in Information Systems. In ECIS (pp. 1493-1504).

Dumas, M., Rosa, M. L., Mendling, J., \& Reijers, H. A. (2013). Introduction to Business Process Management. In Fundamentals of Business Process Management (pp. 1-31). doi:10.1007/978-3-64233143-5 1

Eden, C., \& Huxham, C. (1996). Action Research for Management Research. British Journal of Management, 7(1), 75-86. doi:10.1111/j.14678551.1996.tb00107.x

EFQM. (2001). Excellence One Toolbook. EFQM.

Emery, P. (2010). Past, present, future major sport event management practice: The practitioner perspective. Sport Management Review, 13(2), 158170. doi:10.1016/j.smr.2009.06.003

Ferkins, L., Shilbury, D., \& McDonald, G. (2005). The Role of the Board in Building Strategic Capability: Towards an Integrated Model of Sport Governance Research. Sport Management Review, $8(3), \quad 195-225 . \quad$ doi:10.1016/S14413523(05) 70039-5

Freeman, R. E. (1984). Strategic Management: A Stakeholder Approach. Boston: Pitman.

Gorjão, P. (2012). Portugal and the Straitjacket of the European Financial Crisis. The International Spectator, $\quad 47(4)$, 64-68. doi:10.1080/03932729.2012.743644

Hammer, M. (2010). What is Business Process Management? In J. vom Brocke \& M. Rosemann (Eds.), Handbook on Business Process Management 1 (pp. 3-16). Springer Berlin Heidelberg.

Harmon, P. (2007, November 27). Business Process Methodologies. Retrieved from http://www.bptrends.com/publicationfiles/advis or20071127\%2Epdf
Harmon, P. (2010). The Scope and Evolution of Business Process Management. In J. vom Brocke \& M. Rosemann (Eds.), Handbook on Business Process Management 1 (pp. 37-81). Springer Berlin Heidelberg.

Harmon, P. (Ed.). (2014). Business Process Change, Third Edition: A Business Process Management Guide for Managers and Process Professionals. Boston: Morgan Kaufmann.

Homann, U. (2006). A business-oriented foundation for service orientation. MSDN, Microsoft Corporation. Retrieved from http://msdn.microsoft.com/enus/library/aa479368\%28d=printer\%29

Hoye, R. (2004). Leader-member exchanges and board performance of voluntary sport organizations. Nonprofit Management and Leadership, 15(1), 55-70. doi: $10.1002 / \mathrm{nml} .53$

Huxham, C., \& Vangen, S. (2003). Researching organizational practice through action research: Case studies and design choices. Organizational Research Methods, 6(3), 383-403.

Jeston, J. (2018). Business Process Management: Practical Guidelines to Successful Implementations (4 edition). New York: Routledge.

Jeston, J., \& Nelis, J. (2006). Business Process Management: Practical Guidelines to Successful Implementations (1st ed.). ButterworthHeinemann.

Jones, T., \& Dixon, J. (2011). Hype cycle for business process management (Pesquisa No. G00214214). Gartner Research.

Kaplan, R., \& Norton, D. (1992). The Balanced Scorecard - Measures That Drive Performance. Harvard Business Review, 70(1), 71-79.

Karagiannis, D. (2012). Business Process Management: A Holistic Management Approach. In Information Systems: Methods, Models, and Applications (pp. 1-12). Springer, Berlin, Heidelberg. doi:10.1007/978-3-642-38370-0_1

Kirchmer, M. (2010). Management of Process Excellence. In J. vom Brocke \& M. Rosemann (Eds.), Handbook on Business Process Management 2 (pp. 39-56). Springer Berlin Heidelberg.

Lewin, K. (1946). Action Research and Minority Problems. Journal of Social Issues, 2(4), 34-46. doi:10.1111/j.1540-4560.1946.tb02295.x

Miers, D. (2006). Getting Past the First BPM Project: Developing a Repeatable BPM Delivery Capability. BPTrends, Marec.

Miller, D. (1982). Evolution and Revolution: A Quantum View of Structural Change in Organizations. Journal of Management Studies, 19(2), 131-151.

Miller, D., \& Friesen, P. H. (1983). Strategy-Making and Environment: The Third Link. Strategic Management Journal, 4(3), 221-235.

Møller, C., Maack, C. J., \& Tan, R. D. (2008). What is Business Process Management: A Two Stage Literature Review of an Emerging Field. In L. D. Xu, A. M. Tjoa, \& S. S. Chaudhry (Eds.), Research 
and Practical Issues of Enterprise Information Systems II (pp. 19-31). Springer US.

Porter, M. E. (1985). Competitive advantage: creating and sustaining superior performance. New York: Free Press.

Porter, M. E. (1998). Competitive advantage: creating and sustaining superior performance: with a new introduction (1st Free Press ed). New York: Free Press.

Prahalad, C. K., \& Hamel, G. (1990). The core competence of the corporation. Boston (MA).

Puhakainen, P., \& Siponen, M. (2010). Improving employees' compliance through information systems security training: an action research study. Mis Quarterly, 34(4), 757-778.

Rapoport, R. N. (1970). Three Dilemmas in Action Research With Special Reference to the Tavistock Experience. Human Relations, 23(6), 499-513. doi:10.1177/001872677002300601

Rosemann, M., \& Brocke, J. (2010). The Six Core Elements of Business Process Management. In J. vom Brocke \& M. Rosemann (Eds.), Handbook on Business Process Management 1 (pp. 107-122). Springer Berlin Heidelberg.

Rosen, M. (2012, December). Processes, Value Streams, and Capabilities. Retrieved from http://www.bptrends.com/publicationfiles/1204-2012-COL-BA-

ProcessesValueStreams\%26CapabilitiesRosen.pdf

Rosing, M. von, Scheel, H. von, \& Scheer, A.-W. (2014). The Complete Business Process Handbook: Body of Knowledge from Process Modeling to BPM, Volume 1 (1 edition). Waltham, MA: Morgan Kaufmann.

Rummler, G. A., \& Brache, A. P. (1995). Improving Performance: How to Manage the White Space in the Organization Chart (2nd ed.). Jossey-Bass.

Rummler, G. A., \& Ramias, A. J. (2010). A Framework for Defining and Designing the Structure of Work. In J. vom Brocke \& M. Rosemann (Eds.), Handbook on Business Process Management 1 (pp. 83106). Springer Berlin Heidelberg.

Seippel, $\varnothing$. (2004). The World According to Voluntary Sport Organizations Voluntarism, Economy and Facilities. International Review for the Sociology of Sport, 39(2), 223-232. doi:10.1177/1012690204043465

Sharp, A. (2009). Workflow modeling: tools for process improvement and applications development (2nd ed). Boston: Artech House.

Sharp, A. (2011, November). Capabilities, Agile, and "Process Blindness." Retrieved from http://www.bptrends.com/publicationfiles/11\% 2D01\%2D2011\%2DCOL\%2DPractitioner\%27s \%20Perspective\%2DCapabilities\%2CAgile\%2CP rocess\%20Blindness\%2DSharp\%2Epdf

Shilbury, D., \& Ferkins, L. (2011). Professionalisation, sport governance and strategic capability. Managing Leisure, 16(2), 108-127. doi:10.1080/13606719.2011.559090

Slack, T. (2010). From the locker room to the board room: Changing the domain of sport management. JSM, 10(1).

Slack, T., \& Parent, M. M. (2006). Understanding Sport Organizations: The Application of Organization Theory. Human Kinetics.

Soares, J., Correia, A., \& Rosado, A. (2010). Political Factors in the Decision-making Process in Voluntary Sports Associations. European Sport Management Quarterly, 10(1), 5-29. doi:10.1080/16184740903554033

Stacey, R. D. (2011). Strategic Management and Organisational Dynamics: The challenge of complexity to ways of thinking about organisations (6 edition). Harlow, England New York: Pearson.

Tague, N. R. (2005). The quality toolbox (2nd ed). Milwaukee, Wis: ASQ Quality Press.

Tharenou, P., Donohue, R., \& Cooper, B. (2007). Management research methods. Cambridge [England]; New York: Cambridge University Press.

Thibault, L., Slack, T., \& Hinings, B. (1993). A Framework for the Analysis of Strategy in Nonprofit Sport Organizations. Journal of Sport Management, 7(1), 25-43.

Thiel, A., \& Mayer, J. (2009). Characteristics of Voluntary Sports Clubs Management: a Sociological Perspective. European Sport Management Quarterly, 9(1), 81-98. doi:10.1080/16184740802461744

Tregear, R., Alkharashi, B., Leandro, J., \& Macieira, A. (2010). Establishing the Office of Business Process Management. Retrieved from http://info.leonardo.com.au/establishing-theoffice-of-business-process-management

Weske, M. (2012). Business Process Management: Concepts, Languages, Architectures (2nd ed.). Berlin Heidelberg: Springer-Verlag.

Zairi, M. (1997). Business process management: a boundaryless approach to modern competitiveness. Business Process Management Journal, 3(1), 64-80. doi:10.1108/14637159710161585 